\title{
Newspaper Reading Habits of Private University Students: a Case Study on World University of Bangladesh
}

\author{
Dipika Majumder ${ }^{1}$ Md.Mehedi Hasan ${ }^{2}$ \\ ${ }^{1}$ (Lecturer, Department of Business Administration, World University of Bangladesh) \\ ${ }^{2}$ (Lecturer, Department of Business Administration, World University of Bangladesh)
}

\begin{abstract}
Reading is primarily an intellectual activity of learning new things, developing new ideas and it provides a sense of completeness. Newspaper is a wonder of modern science it carries news and views of home and abroad to us. Newspaper reading is a habituated reading which influences readers to discover and enter the store house of knowledge in daily basis. The aim of present study is to investigate the level of newspaper reading habits of students. The target population of the study consist $1^{\text {st }}$ year to postgraduate students of science commerce and arts faculties of World University of Bangladesh. On the basis of questionnaire survey the study made some possible recommendation to improve the newspaper reading habits of the respondents.
\end{abstract}

Key words: Habit, Newspaper, Reading, Students, University.

\section{Introduction}

Newspaper creates reading habits and easily differentiates people who read and who do not. Reading is the art of learning something. Newspaper is the store house of knowledge and provides knowledge of different tests and kinds of different segments of the society. It is equally important for the entire people form student to government officials. Reading builds vocabulary skills and background knowledge that strengthens reading skills and increases the enjoyment of reading (Strommen \& Mates, 2004)

Student's willingness and unwillingness to read newspaper is an indicator to know their current reading habits.

A newspaper reading habit is somewhat established by the time a person reaches the traditional college age of 18 (Stone \& Wetherington, 1979) and is typically firmly established by the time a person reaches 25 to 30 years of age (Clark, Martire \& Bartolomeo, 2004). Like all other habits newspaper reading habit also influenced by the reading habits of parents. Stone and Wetherington (1979) assert that the newspaper reading behavior of parents is a stronger predictor of habit formation than programs to establish readership habits, such as the Newspapers in Education program. Newspaper reading habits not only creates a habit of reading but also open the doors of self improvements. The practice of reading, a newspaper has been associated with improvement in students' attitudes toward reading overall (DeRoche, 1981; Palmer, Fletcher \& Shapley, 1994; Seely, 1980). According to, McFarlin students must feel that they are part of a "reading club," and newspaper material must relate to something they already known about.

\section{I.I Background of the Study}

The study is conducted in a growing private university in Bangladesh. World University of Bangladesh having its 8000 students and several departments and four specific luxurious campuses provides quality education for all part of the society. The university believes in quality education having minimum cost, this inclusion strategy attracts huge number of students from different demographic characteristics. So the population and sample size drawn from the university is a well choice to meet the research requirements.

\section{I.I.II Rational of the Study}

The study choose World university of Bangladesh instead of going other universities in Bangladesh as it is working place of researchers' so that establishing a mutual co-operative relation with respondents are easy, facts and essential information can be drawn effectively and efficiently.

\section{I.II Objectives}

To explore the level of newspaper reading habits of respondents.

To identify the factors affecting reading habit

To provide possible recommendations to make newspaper reading more convenient.

\section{I.II.I Limitations of the Study.}

Local empirical literature on newspaper reading habits is very lacking, as a result, the researchers had to rely mostly on literature from developed countries. This may not give a true picture, because reading habits in one country may differ from another country. 


\section{Methodology}

The study is completely based on primary data, simple observation and structured interview taken place through an open end and closed end questionnaire. 200 randomly selected respondents were distributed questionnaire. After obtaining information form questionnaire completion, the data was analyzed through simple percentage analysis. A well designed self made questionnaire used as a data analysis tool.

\section{Literature Review}

Previously a numerous studies have been made in the field of newspaper reading habits of students. Researchers all over the world have contributed through their extensive findings and recommendations.

According to the Newspaper Association of America, six in 10 adults who had high exposure to newspapers in the classroom are regular newspaper readers (Clark, Martire, \& Bartolomeo, 2004). The class discussion about free expression and civic affairs increased newspaper readership among college students. (Ross and Andsager, 2000) In the analysis of types of newspaper students read Bressers and Bergen (2002) found that university students were more likely to read their campus newspaper than other newspapers in print or online newspapers. In recent study Bndaka (2007) found that newspaper articles help to develop students' reading skills in senior high school. Newspaper provides wide wings to know the outer world along with class participation this is intended to be a win-win arrangement for schools and newspapers. Schools get educational content delivered to their door each morning while newspapers strengthen their current and (they hope) future readership numbers (Meirick \& Sullivan, 2001; Newton, 1985). Stone and Wetherington (1979) found that the habit of newspaper reading depends on several factors These include reading at least three or more times per week, preferable daily, reading more than 15 minutes a day, having a stable method of getting the paper, and having a particular time and place to read the paper. Researchers have suggested publishers tailor content to fit the younger audience's information wants and needs (Gaultney, 1994; Morton, 2003; Pohlig, 2003). Others have studied what type of content appeals to younger adults (Kohut, 2002; Jeffres \& Atkin, 1995; Morton, 2002) some research has shown newspapers in the classroom improve literacy skills and attitudes toward reading newspapers (Newton, 1985; Palmer, Fletcher \& Shapley, 1994; Seely, 1980; Stone, 1988; Sullivan, 2002).)

\section{Data Analysis}

Table -1 Size of the sample based on departments

\begin{tabular}{|l|c|c|}
\hline Name of departments & Questionnaire distributed & Percentage [\%] \\
\hline BBA & 65 & 32.5 \\
\hline EEE & 15 & 7.5 \\
\hline CSE & 15 & 7.5 \\
\hline Civil & 15 & 7.5 \\
\hline Textile & 15 & 7.5 \\
\hline English & 15 & 7.5 \\
\hline Law & 15 & 7.5 \\
\hline Pharmacy & 15 & 7.5 \\
\hline MBA & 15 & 7.5 \\
\hline Total & 200 & 100 \\
\hline
\end{tabular}

Source: Field Survey 2013

Interpretation: Table-1shows that in world university of Bangladesh total students are around 8000, the table depicts the questionnaire distributed among respondents was 200. Out of these respondents maximum number $65(32.5 \%)$ were from bachelor of business administration department, as because the department contained a major portion of total student of that university. The numbers of students in other departments like EEE, CSE, Civil Engineering, textile, English, law, pharmacy and MBA are (7.5\%) respectively.

Table -2 Size of the sample based on level of the respondents

\begin{tabular}{|l|c|c|}
\hline Level of students & Questionnaire distributed & Percentage [\%] \\
\hline First year & 55 & 27.5 \\
\hline Second year & 46 & 23 \\
\hline Third year & 37 & 18.5 \\
\hline Fourth year & 41 & 20.5 \\
\hline Post graduates & 21 & 10.5 \\
\hline Total & 200 & 100 \\
\hline
\end{tabular}

Source: Field Survey 2013

Interpretation: Table- 2 shows that the year wise classification of sample size. Among the 200 respondents $27.5 \%$ are from $1^{\text {st }}$ year. The largest numbers of questionnaire distributed among $1^{\text {st }}$ year students because of their height rate of presence in class room. 23\% questionnaires were distributed among $2^{\text {nd }}$ year students and $10.5 \%$ among post graduate students. This shows the decline rate of presence in the class room of students. 
Table -3 Language preference of respondents

\begin{tabular}{|l|c|c|c|c|c|c|}
\hline Language & First year $(\%)$ & Second year $(\%)$ & Third year $(\%)$ & Fourth year $(\%)$ & Post graduation $(\%)$ & Average \% \\
\hline Bangla & $40(20)$ & $30(15)$ & $21(10.5)$ & $23(11.5)$ & $11(5.5)$ & 62.5 \\
\hline English & $15(7.5)$ & $16(8)$ & $16(8)$ & $18(9)$ & $10(5)$ & 37.5 \\
\hline Total & $55(27.5)$ & $46(23)$ & $37(18.5)$ & $41(20.5)$ & $21(10.5)$ & 100 \\
\hline
\end{tabular}

Source: Field Survey 2013

Interpretation: Table-3 shows that majority of the respondent $(62.5 \%)$ prefer to read newspaper in Bangla, as it is their mother language, whereas $37.5 \%$ respondents prefer to read English newspaper. The table also shows that respondents from $1^{\text {st }}$ year $(20 \%)$ prefer to read bangle newspaper mostly because they have habituated their academic books in bangle medium in their higher secondary level. the table also disclose that respondents prefer to read English newspaper gradually from $1^{\text {st }}$ year to post graduation because they need better English for their future betterment.

Table -4 Gender of the respondents

\begin{tabular}{|l|c|c|c|c|c|c|}
\hline Gender & $\begin{array}{c}\text { First year } \\
(\%)\end{array}$ & $\begin{array}{c}\text { Second } \\
\text { year }(\%)\end{array}$ & $\begin{array}{c}\text { Third year } \\
(\%)\end{array}$ & $\begin{array}{c}\text { Fourth year } \\
(\%)\end{array}$ & $\begin{array}{c}\text { Post graduation } \\
(\%)\end{array}$ & $\begin{array}{c}\text { Average } \\
\%\end{array}$ \\
\hline Male & $35(17.5)$ & $28(14)$ & $26(13)$ & $28(14)$ & $16(8)$ & 66.5 \\
\hline Female & $20(10)$ & $18(9)$ & $11(5.5)$ & $13(6.5)$ & $5(2.5)$ & 33.5 \\
\hline Total & $55(27.5)$ & $46(23)$ & $37(18.5)$ & $41(20.5)$ & $21(10.5)$ & 100 \\
\hline
\end{tabular}

Source: Field Survey 2013

Interpretation: Table-4 shows that largest parts of the respondents $(66.5 \%)$ are from male group and smallest parts (33.5\%) from female group. The socio-economic condition of Bangladesh does not allow female to study in private university as it is expensive and parents like to spend money for their male children because of high expectation. The table also clearly shows the gradual dropout rate of female respondents lowest in $1^{\text {st }}$ year and highest in post graduation.

Table -5 Times spent by respondents reading newspaper

\begin{tabular}{|c|c|c|c|c|c|c|}
\hline Time spent & $\begin{array}{c}\text { First year } \\
(\%)\end{array}$ & $\begin{array}{c}\text { Second yea } \\
\mathrm{r}(\%)\end{array}$ & Third year (\%) & Fourth year (\%) & Post graduation (\%) & Average\% \\
\hline $1-2$ hours & $17(8.5)$ & $15(7.5)$ & $12(6)$ & $15(7.5)$ & $8(4)$ & 33.5 \\
\hline Total & $55(27.5)$ & $46(23)$ & $37(18.5)$ & $41(20.5)$ & $21(10.5)$ & 100 \\
\hline
\end{tabular}

Source: Field Survey 2013

Interpretation: Table-5 shows that most of the respondents $(51.5 \%)$ spent less than one hour in reading newspaper while only $15 \%$ respondents spent more than two hours daily in reading newspaper. The table also indicates that respondents from $1^{\text {st }} 2^{\text {nd }}$ and $3^{\text {rd }}$ year spent less time in reading newspaper whereas respondents from $4^{\text {th }}$ year and post graduates gradually spent more time in reading newspaper as it helps to develop academic and non-academic knowledge which can help to face competitive exam.

Table -6 Sources of newspaper

\begin{tabular}{|l|c|c|c|c|c|c|}
\hline Sources & $\begin{array}{c}\text { First year } \\
(\%)\end{array}$ & $\begin{array}{c}\text { Second year } \\
(\%)\end{array}$ & $\begin{array}{c}\text { Third year } \\
(\%)\end{array}$ & $\begin{array}{c}\text { Fourth year } \\
(\%)\end{array}$ & $\begin{array}{c}\text { Post graduation } \\
(\%)\end{array}$ & $\begin{array}{c}\text { Average } \\
\%\end{array}$ \\
\hline Self subscription & $15(7.5)$ & $14(7)$ & $12(6)$ & $19(9.5)$ & $13(6.5)$ & 36.5 \\
\hline Library & $19(9.5)$ & $14(7)$ & $10(5)$ & $12(6)$ & $3(1.5)$ & 29 \\
\hline Mess/Hostel & $21(10.5)$ & $18(9)$ & $15(7.5)$ & $10(5)$ & $5(2.5)$ & 34.5 \\
\hline Total & $55(27.5)$ & $46(23)$ & $37(18.5)$ & $41(20.5)$ & $21(10.5)$ & 100 \\
\hline
\end{tabular}

Source: Field Survey 2013

Interpretation: Table-6 shows that self subscription (36.5\%) is the main form of source of newspaper for the respondent. $29 \%$ respondents read newspaper in university library and $34.5 \%$ respondents read newspaper in hostels. The table also shows that respondents from upper classes $4^{\text {th }}$ year $(9.5 \%)$ and postgraduates $(6.5 \%)$ mainly the self subscriber of newspaper.

Table -7 Medium of newspaper

\begin{tabular}{|l|c|c|c|c|c|c|}
\hline Medium & $\begin{array}{c}\text { First year } \\
(\%)\end{array}$ & Second year (\%) & $\begin{array}{c}\text { Third year } \\
(\%)\end{array}$ & $\begin{array}{c}\text { Fourth year } \\
(\%)\end{array}$ & $\begin{array}{c}\text { Post graduation } \\
(\%)\end{array}$ & $\begin{array}{c}\text { Average } \\
\%\end{array}$ \\
\hline Print copy & $38(14)$ & $27(13.5)$ & $22(11)$ & $27(13.5)$ & $14(7)$ & 64 \\
\hline $\begin{array}{l}\text { Internet } \\
\text { version }\end{array}$ & $17(8.4)$ & $19(9.5)$ & $15(7.5)$ & $14(7)$ & $7(3.5)$ & 36 \\
\hline Total & $55(27.5)$ & $46(23)$ & $37(18.5)$ & $41(20.5)$ & $21(10.5)$ & 100 \\
\hline
\end{tabular}

Source: Field Survey 2013

Interpretation: Table-7shows that majority of the respondents $(64 \%)$ read newspaper in print copy while rest of them (36\%) read internet version of newspaper, and the reason is still internet is not so convenient to the respondents. 
Table -8 Choice of daily newspaper

\begin{tabular}{|l|c|c|c|c|c|c|}
\hline Name of newspaper & $\begin{array}{c}\text { First year } \\
(\%)\end{array}$ & $\begin{array}{c}\text { Second year } \\
(\%)\end{array}$ & $\begin{array}{c}\text { Third year } \\
(\%)\end{array}$ & $\begin{array}{c}\text { Fourth year } \\
(\%)\end{array}$ & $\begin{array}{c}\text { Post graduation } \\
(\%)\end{array}$ & $\begin{array}{c}\text { Average } \\
\%\end{array}$ \\
\hline Prothom alo & $28(14)$ & $19(9.5)$ & $15(7.5)$ & $20(10)$ & $8(4)$ \\
\hline Ittefak & $3(1.5)$ & $5(2.5)$ & $3(1.5)$ & $2(1)$ & $4(.5)$ \\
\hline Somokal & $4(2)$ & $2(1)$ & $3(1.5)$ & $1(.5)$ & $1(.5)$ \\
\hline Amar desh & $4(2)$ & $1(.5)$ & $2(1)$ & $0(0)$ & $2(1)$ & 7 \\
\hline Noya digganta & $2(1)$ & $0(0)$ & $3(1.5)$ & $1(.5)$ & $2(1)$ \\
\hline Amader somoy & $3(1.5)$ & $2(1)$ & $2(1)$ & $3(1.5)$ & 0.5 & 4 \\
\hline Bangladesh Poridin & $2(1)$ & $3(1.5)$ & $1(.5)$ & $0(0)$ & $1(.5)$ & 3 \\
\hline Star & $5(2.5)$ & $6(3)$ & $3(1.5)$ & $8(4)$ & $3(1.5)$ & 13.5 \\
\hline Observer & $3(1.5)$ & $1(.5)$ & $3(1.5)$ & $4(2)$ & $2(1)$ & 6.5 \\
\hline Independent & $1(.5)$ & $2(1)$ & $1(.5)$ & $2(1)$ & $1(.5)$ \\
\hline Total & $55(27.5)$ & $46(23)$ & $37(18.5)$ & $41(20.5)$ & $21(10.5)$ & 100 \\
\hline
\end{tabular}

Source: Field Survey 2013

Interpretation: Table-8shows that $45 \%$ respondents prefer to read Daily Prothom Alo among bangle newspaper while only $13.5 \%$ of the respondents prefer to read Daily Star among English newspaper because both Prothom Alo and Daily Star got huge public response and recognition.

Table -9 Choice of topics of newspaper

\begin{tabular}{|l|c|c|c|c|c|c|}
\hline $\begin{array}{l}\text { Topics of } \\
\text { newspaper }\end{array}$ & $\begin{array}{c}\text { First year } \\
(\%)\end{array}$ & $\begin{array}{c}\text { Second year } \\
(\%)\end{array}$ & $\begin{array}{c}\text { Third year } \\
(\%)\end{array}$ & $\begin{array}{c}\text { Fourth year } \\
(\%)\end{array}$ & $\begin{array}{c}\text { Post graduation } \\
(\%)\end{array}$ & $\begin{array}{c}\text { Average } \\
\%\end{array}$ \\
\hline Editorial & $2(1)$ & $1(.5)$ & $1(.5)$ & $4(2)$ & $2(1)$ \\
\hline Advertisement & $5(2.5)$ & $2(1)$ & $2(1)$ & $2(1)$ & 5 \\
\hline Politics & $5(2.5)$ & $3(1.5)$ & $3(1.5)$ & $5(2.5)$ & $3(.5)$ \\
\hline Entertainment & $15(7.5)$ & $12(6)$ & $10(5)$ & $8(4)$ & $4(1.5)$ & 9.5 \\
\hline Sports & $15(7.5)$ & $15(7.5)$ & $12(6)$ & $10(5)$ & 24.5 \\
\hline Sensational news & $3(1.5)$ & $4(2)$ & $4(2)$ & $2(1)$ & $1(.5)$ & 7 \\
\hline Cultural news & $6(3)$ & $5(2.5)$ & $3(1.5)$ & $2(1)$ & $1(.5)$ \\
\hline Economics & $2(1)$ & $3(1.5)$ & $2(1)$ & $7(3.5)$ & 8.5 \\
\hline Local news & $2(1)$ & $1(.5)$ & $0(0)$ & $1(.5)$ & $2(1)$ \\
\hline Total & $55(27.5)$ & $46(23)$ & $37(18.5)$ & $41(20.5)$ & $21(.5)$ \\
\hline
\end{tabular}

Source: Field Survey 2013

Interpretation: Table-9 shows that most of the respondents prefer to read sports news (29\%) and entertainment news $(24.5 \%)$. The table also shows that the choice of topic cover also varies gradually from $1^{\text {st }}$ year to post graduation respondents.

Table-10Motives of reading newspaper

\begin{tabular}{|l|c|c|c|c|c|c|}
\hline Motive & $\begin{array}{c}\text { First year } \\
(\%)\end{array}$ & Second year $(\%)$ & $\begin{array}{c}\text { Third year } \\
(\%)\end{array}$ & $\begin{array}{c}\text { Fourth year } \\
(\%)\end{array}$ & $\begin{array}{c}\text { Post graduation } \\
(\%)\end{array}$ & $\begin{array}{c}\text { Average } \\
\%\end{array}$ \\
\hline For fun & $15(7.5)$ & $11(5.5)$ & $8(4)$ & $5(2.5)$ & $2(1)$ & 20.5 \\
\hline $\begin{array}{l}\text { Improve general } \\
\text { knowledge }\end{array}$ & $8(9)$ & $17(8.5)$ & $15(7.5)$ & $25(12.5)$ & $10(5)$ \\
\hline Passing leisure time & $10(5)$ & $10(5)$ & $5(2.5)$ & $4(2)$ & 42.5 \\
\hline Hobby & $12(6)$ & $8(4)$ & $9(4.5)$ & $7(3.5)$ & $5(2.5)$ & 20.5 \\
\hline Total & $55(27.5)$ & $46(23)$ & $37(18.5)$ & $41(20.5)$ & $21(10.5)$ & 100 \\
\hline
\end{tabular}

Source: Field Survey 2013

Interpretation: Table-10 shows that most of the respondents $(42.5 \%)$ read newspaper for improving their general knowledge. The table also shows that this rate is highest for $4^{\text {th }}$ year and post graduation respondents than other respondents.

Table -11Inspiration of reading

\begin{tabular}{|l|c|c|c|c|c|c|}
\hline Inspiration & $\begin{array}{c}\text { First year } \\
(\%)\end{array}$ & $\begin{array}{c}\text { Second year } \\
(\%)\end{array}$ & $\begin{array}{c}\text { Third year } \\
(\%)\end{array}$ & $\begin{array}{c}\text { Fourth year } \\
(\%)\end{array}$ & $\begin{array}{c}\text { Post graduation (\%) } \\
\%\end{array}$ & $\begin{array}{c}\text { Average } \\
\%\end{array}$ \\
\hline Parents & $18(9)$ & $12(6)$ & $10(5)$ & $8(4)$ & $2(1)$ & $1(.5)$ \\
\hline Siblings & $9(4.5)$ & $7(3.5)$ & $4(2)$ & $2(1)$ & $3(1.5)$ & 11.5 \\
\hline Teachers & $10(5)$ & $9(4.5)$ & $5(2.5)$ & $5(2.5)$ & $7(2)$ & 16 \\
\hline Friends & $11(5.5)$ & $8(4)$ & $7(3.5)$ & $7(3.5)$ & 18 & 29.5 \\
\hline Self & $7(3.5)$ & $10(5)$ & $12(6)$ & $19(8.5)$ & $21(10.5)$ & 100 \\
\hline Total & $55(27.5)$ & $46(23)$ & $37(18.5)$ & $41(20.5)$ & $25)$ & 20 \\
\hline
\end{tabular}

Source: Field Survey 2013

Interpretation: Table-11 shows that parents are main source of inspiration for $1^{\text {st }} 2^{\text {nd }}$ and $3^{\text {rd }}$ year respondents. While $4^{\text {th }}$ year and postgraduates respondents read newspaper from their self inspiration as they can understand the importance of newspaper reading in their life. Teachers play a vital role to inspire respondents in reading newspaper in all level. 


\section{IV.I Findings}

The majority of the respondents read newspaper in Bangla. Most of the respondents are from male group. Majority of the respondents spent less than one hour in reading newspaper. Self subscription is the main source of newspaper. Print copy is still used as the best medium of newspaper for the respondents. Most of the respondents read mainly Daily Prothom Alo and Daily Star .Most of the respondents prefer to read sports and entertainment news. The main purpose of reading newspaper is to improve general knowledge of respondents.

\section{Conclusion \& Recommendation}

Students are the future of a nation and newspaper reading can make them a good citizen who can contribute for themselves as well as for their county whenever the necessity is. To make newspaper reading easy and affordable to the respondents the study likes to recommend in the following way

Parents should provide a supporting environment to influence a habit of reading in children at the young age. All the concerned parties should influence students to read and should provide well cooperation to read newspaper. University library should provide adequate number of newspaper and facilitate the service properly to read newspaper as many respondents as they can. A sense has to develop to read English newspaper. In university premises internet facilities should be widen enough to meet the need of the respondents.

\section{Acknowledgements}

We must express our gratitude and thanks to our beloved parents whose love and cooperation make us as we today. Our thanks must go to a large number of people whom we have not personally met but whose writings and research, we have drawn in putting together to make our effort successful.

\section{References}

[1] Bndaka, Eleni (2007). Using newspaper articles to develop students' Reading skills in senior high school. The Reading Matrix, 7 (1)

[2] Clark, Martire, \& Bartolomeo (2004). Growing lifelong readers: A study of the impact of student involvement with newspapers on adult readership. Unpublished study prepared for the Newspaper Association of America Foundation. Retrieved June 14, 2006, from http://www.nieworld.com/teachers/lifelongreaders.htm.

[3] Klare, G. R. (1984). Readability, in: P. D. Pearson (Ed.) Handbook of Reading Research(New York, Longman).

[4] Macdonald-Ross, M. \& Scott, B. (1995). Results of the survey of OU students' reading skills. Text and Readers Programme: Technical Report \#3 (Milton Keynes, Institute of Educational Technology, Open University).

[5] McLuhan, M. (1994). Understanding Media - The Extensions of Man, Cambridge, MA, MIT Press.

[6] Merrill, J.C. and Lowenstein, R.L. (1971). Media, Message, and Men: New Perspectives in Communications. New York: David McKay and Company Inc.

[7] Morris, M. and Ogan, C. (1996). The Internet as Mass Medium. Journal of Communication, 46(1). 39-52

[8] Mulopoulos, Chryss (1985). Trends in multicultural programming. Canadian Library Journals, 42(1), 23-25.

[9] Napoli, J. and Ewing, M. (1998). The Media Habits and Internet Practices of the Net Generation. Perth, Australia: Curtain University of Technology.

[10] O'Brien, M. (1999). Newspaper on the Internet- With a Case Study of the Nando Time. Research Paper.

[11] Palmer, J.W. and Eriksen, L.B. (1999). Digital Newspapers Explore Marketing on the Internet. Communication of the ACM, 42(9). $33-42$.

[12] Ross, S. D., \& Andsager, J. (2000). Solutions to circulation woes?: Free expression as a predictor of news seeking. Newspaper Research Journal, 21(1), 77-92. Retrieved April 21, 2005, from InfoTrac OneFile.

[13] Robinson, J.P., Barth, K., and Kohut, A. (1997). Social Impact Research: Personal Computers, Mass Media and use of Time, Social Science Computer Review, 15(1). 65-82.

[14] Strommen, L.T., \& Mates, B.F. (2004). Learning to love reading: Interviews with older children and teens: students in sixth and ninth grades were surveyed to determine attitudes toward reading and identify factors associated with the development of a love of reading. Journal of Adolescent \& Adult Literacy, 48(3), 188-201.

[15] Stone, G. C., \& Wetherington, R. V. (1979). Confirming the newspaper reading habit. Journalism Quarterly, 56, 554-561, 566.

[16] Shahriza, Nor (2007). Reading habits and attitude in the digital age: Analysis of gender and academic programm differences in Malaysia. The Electronic Library, 25(3). 285-98.

[17] Somsong, Sangkaeo (1999). Reading habit promotion in ASEAN libraries. 65 ${ }^{\text {th }}$ IFLA Council and General Conference Bangkok, Thailand. 28 August 1999. Sparkes, V.M. (1983). Public Perception of and Reaction to Multi-channel Cable Television Service. Journal of Broadcasting, 27: 163-175.

[18] Stadler, Alois (1980). Children of guest worker in Europe: Social and cultural needs in relation to library services. Library Trends, 29(2). 325-334. Stephens, M. (1998). Which Communications Revolution is it, Anyway? Journalism and Quarterly, 75(1). 9-13.

[19] Tsao, C.J. and Sibley, S.D. (2004). Displacement and Reinforcement Effects of the Internet and other Media as Sources of Advertising Information. Journal ofAdvertising Research, pp. 126-142. Van Der, R. J.W. (2005). Impacts of the Internet on Newspaper in Europe. International Journal of Communication Studies, 67(1). 107-120.

[20] Yilmaz, Bülent. (2000). Reading and library usage habits of the students whose mother tongue is Turkish in Vienna, Austria." 66th IFLA council and General conference Jerusalem, Israel: 13-18. 